\title{
Dynamic Relationship Between Imports and Economic Growth in Pakistan
}

\author{
Muhammad Yamman Khan \\ Visiting Faculty, Karachi University Business School, University of Karachi \\ Dr Saima Akhtar \\ Assistant Professor, Department of Public Administration, University of Karachi \\ Dr Sakina Riaz \\ Assistant Professor, Department of Social Work, University of Karachi
}

\begin{abstract}
This research paper examines the causal relationship between imports and economic growth along with the impact of economic growth on imports in the perspective of Pakistan using the Granger causality test and simple regression test. The research aims to evaluate the relationship between the respective variables by using the data for a period of 40 years from 1975 to 2014 . The result revealed that there is a causal relationship between imports and economic growth and found the evidence of bi-directional causality between imports and economic growth in Pakistan. Similarly, the result showed that there is a significant causal relationship between economic growth and imports in Pakistan. On the basis of Granger's causality test, the positive and significant relationship between the respective variables reflects that imports of capital goods such as machinery group, chemicals, equipment, etc. translate in to the economic productivity and growth along with the imports of consumer goods that also contributes towards the export oriented productivity indirectly. For further research, the right mix of the categories and products should be examined to accelerate the pace of economic growth through imports in Pakistan.
\end{abstract}

Keywords: Import, Economic Growth, Granger Causality, Bi-directional, Causal Relationship

DOI: $10.7176 / \mathrm{JESD} / 10-10-08$

Publication date:May $31^{\text {st }} 2019$

\section{INTRODUCTION}

Economists who belong to the classical perspective and neo-classical perspective argue that the involvement in international trade is a major source of economic growth. Various reasons can be advocated in support for this perspective as trade promotes the economic activity by enhancing the exports that directly contributes in the economic development. Moreover, it is a source of generating foreign exchanges that assists in importing the raw materials and other required inputs. Extensive research and literature has focused on exports as the prime driver of the economy and it's the fundamental unit of the economic growth. Various theories assume that there is a casual relationship between exports and economic growth. As per the theories, exports channelize the economic growth through innovation, upgraded capacity and improved productivity. Considering the significance of exports in the economic growth, various countries across the globe have formulated policies and strategies to increase their exports that can translate into economic growth. An extensive amount of empirical data and literature has been contributed on the relationship between exports and growth. However, there is a gap that needs to be tapped pertaining to the relationship between imports and growth. The reason behind this lack of focus towards the research contribution between imports and economic growth is particularly due to its complication in comparison to the export and growth.

One of the methods to analyze the role of trade is to examine the impact of imports on economic growth. Most of the developing countries across the globe strive to minimize their imports to reduce their trade deficit or to improve their trade balance because a major portion of their foreign exchange is consumed on imports. These developing countries come up with the import substitution industrialization strategy to replace the imports through domestic production. For this strategy, government must either impose tariffs and quota or it should subsidize the domestic production to compete with the imported goods. (Hogendorn, 1996)

Both economic and non-economic factors determine the demand for imports in any country. These include all the economic activities, external economic scenarios, production capacity, inflation rates, exchange rates etc. However, relative prices and real income contribute significantly laying a huge impact on demand for imports. Rivera Baitz (1985) advocates that an increased economic activity would ensure the rise in imports as the higher income results in more consumption. This leads towards the implication that import is linked with the economic growth. In contrast to this, Lee (1995) states that any distortions and interference with the imports of capital goods will result in the higher prices of the imported items that will slow down the growth pace and will force the economy to utilize the domestic goods. By imposing import quota and tariffs on imports and subsidizing the domestic production may result in the minimal production of exporting items, as few import items like capital 
goods are fundamental for the production of the export merchandise. Consolidating and squeezing such imports will result in low economic growth and hamper the export performance. Lee (1995) argued that the impact of imports on economic growth is very important and found that those capital goods that are imported have more productivity rather than locally produced capital goods. Recent researches and literatures also takes in to account the role of import on export promotion indicating that imports of inputs as a significant determinant between economic growth and trade.

Various growth models have highlighted the significance of imports as a major platform for knowledge and foreign technology that is transferred in to a local economy. (Grossman and Helpman, 1991; Lee, 1995:91-110; Mazumdar, 2001:209-224) Furthermore, it is a recognized belief that imports lay an important impact in those countries whose manufacturing base is formulated on exported oriented industries. (Esfahani, 1991:93-116; Serletis, 1992:135-145; Riezman et. al, 1996:77-110; Liu et. al., 1997:1679-1686) Similarly, Riezman, Whiteman and Summers (1995) carried out an investigation pertaining to export led growth that also focused on the imports in the model. It was revealed that in few of the selected countries, the import growth was directly linked to the economic growth.

The purpose of this paper is to examine and empirically investigate the casual relationship between imports and economic growth in Pakistan. The main reason behind focusing on Pakistan is to examine and understand the impact of imports on the economic growth of Pakistan and to establish whether the economic growth determines the increase in imports and vice versa. Imports in the developing countries are normally evaded and more attention is directed towards exports. Even highlighting the benefits of imports is full of technicalities and complexity that raises a lot of questions and concerns. The volume of imports in Pakistan is more than the volume of exports that highlights the importance the need to investigate its impact on growth. A myopic and restricted paradigm regarding exports alone will not result in comprehending the holistic view of trade and its impact on the economy. Another reason to work on this aspect is to fill the gap by examining the role of import on economic growth in Pakistan as previous researches have failed to give the due importance to it.

\section{LITERATURE REVIEW}

The relationship between imports and economic growth has gone through extensive empirical work. The investigation is usually conducted around the basis of how the imports impact on the economic growth of any country. Studies that have been conducted on its significance revealed that imports have a relationship with the economic growth. To address the previous researches contributed on the issue of causality of imports and economic growth, few of the studies have been summarized as follows:

Yuhong, Li and et. al. (2010) analyzed the data and performed con-integration with respect to imports and exports in China. The results revealed that the growth of imports enhanced the economic growth in China.

Asafu-Adjaye et al (1999) analyzed three variables that included exports, real output and imports with a period from 1960 to 1994. The result revealed that there is no evidence of the export led growth hypothesis and evidence of the presence of the causal relationship between the given variables.

Hussain M and Saaed A. (2014) analyzed the impact of exports and import on economic growth in Saudi Arabia comprising of annual data for a period from 1990 to 2011. The co integration test and Granger causality test were used in the empirical analysis. The results revealed that causation between imports and economic growth was statistically insignificant.

Kotan and Saygili (1999) analyzed the two unique models to evaluate an import demand for Turkey. The results showed that in the long run, the income level lays a significant impact on imports.

Baharumshah and Rashid (1999:389-406) found out the presence of a long term relationship between exports, GDP and imports. The result based on the empirical findings revealed that the import of foreign technology is the main factor for the long term growth in Malaysian economy. Similarly, Awokuse's (2007:389-395) examined the variables of imports and exports on economic growth in Poland, Czech Republic and Bulgaria. The result showed that too much focus of the past researches on the impact of exports alone as the main driver of growth may be misrepresentative and misleading excluding imports.

Rana (2002) conducted her research pertaining to the impact of imported and domestic technologies on domestic firms and revealed that the impact was statistically significant of imported technologies on productivity in Indian manufacturing firms.

\section{OVERVIEW}

\section{Imports in Pakistan}

Like other developing nations, Pakistan has been enjoying the sharp decline in the global oil prices in the recent times that reflect through its import bill. A major portion of the Pakistan's import bill (approximately one-third) comprises of petroleum products that includes the crude oil as well. This was a result of major plummet of the international oil prices that fell from US \$ 107 per barrel to US \$ 60 per barrel in April 2015. This particular fluctuation in the international prices laid an impact on the import bill of Pakistan during July-April 2014-15. The 
import target was around US\$ \$ 44.2 billion for the year 2014-15. During the first ten months of 2014-15, the imports could only go up by 1.8 percent in comparison to the last year. Moreover, the major portion of saving that came from petroleum group approximately US\$2,366 was offset by the increase in import bill of machinery items, food, textile, agriculture, transport etc.

\begin{tabular}{|l|c|}
\hline Imports & Amount \\
\hline Machinery Group & \$880.9 Million \\
\hline Food & \$751.4 Million \\
\hline Transport Group & \$275.7 Million \\
\hline Agriculture and Chemicals & \$587.4 Million \\
\hline Textile Groups & \$558.3 Million \\
\hline
\end{tabular}

Source: Economic Survey of Pakistan 2014-15

The impact of the import of machinery group results in the acceleration of economic activity in Pakistan. In spite of the overall slow pace of growth in the import bill, the import of machinery group stood at 16.9 percent during July-April, 2014-15.

Trends of Import in Last 2 Decades in Pakistan

The imports of Pakistan have seen fluctuations in the past but has exceeded far more than the exports of Pakistan. The trend of last 20 years of imports in Pakistan is illustrated as follows:

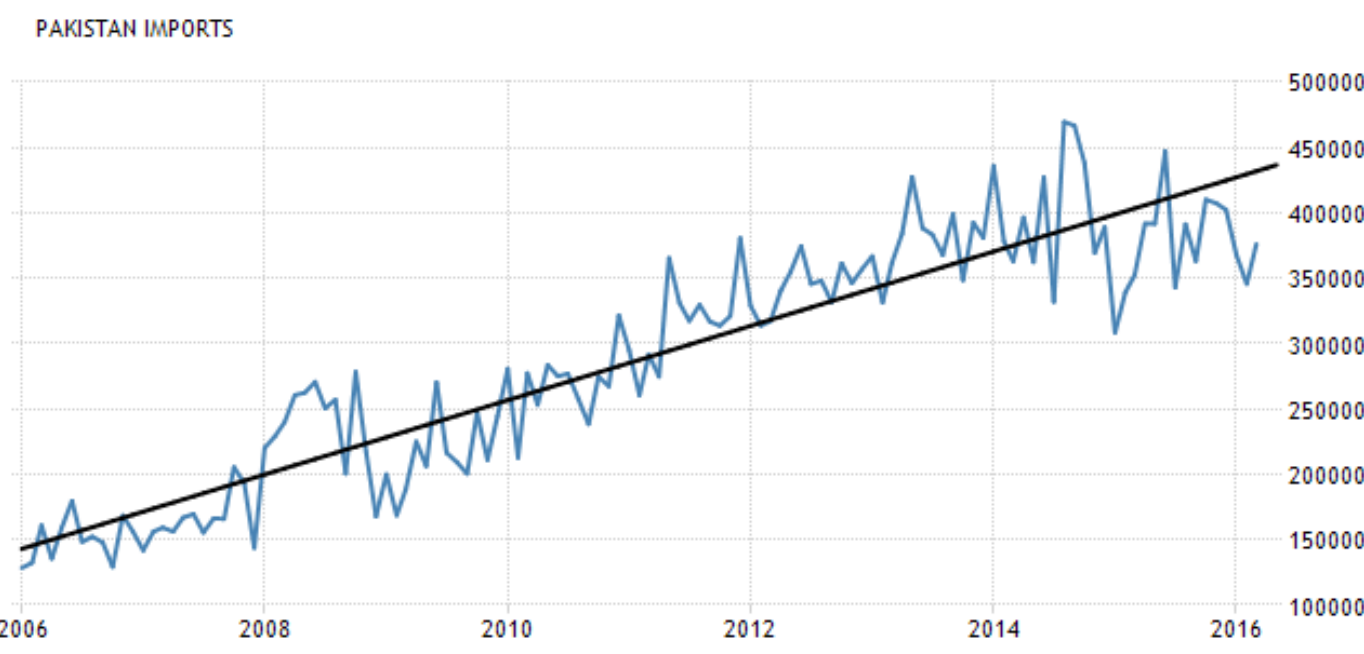

Trends in Monthly Imports: Following table depicts the monthly imports incurred during July-April 2014-15 that was mostly same with a difference in three major months of August, September, and October. Imports on average rose by US\$ 48.0 million per month as per the table. The average of imports was $\$ 3,806$ million as compared to $\$ 3,758$ million during July-June 2013-14.
Table 8.10: Monthly Imports

\begin{tabular}{l|r|r}
\hline \multirow{2}{*}{ Month } & \multicolumn{2}{|c}{ (\$ Million) } \\
\cline { 2 - 3 } & $\mathbf{2 0 1 3 - 1 4}$ & $\mathbf{2 0 1 4 - 1 5 ~ P}$ \\
\hline July & 3,814 & 3,365 \\
\hline August & 3,572 & 4,718 \\
\hline September & 3,791 & 4,561 \\
\hline October & 3,281 & 4,266 \\
\hline November & 3,651 & 3,630 \\
\hline December & 3,561 & 3,859 \\
\hline January & 4,137 & 3,063 \\
\hline February & 3,597 & 3,323 \\
\hline March & 3,621 & 3,488 \\
\hline April & 4,053 & 3,790 \\
\hline May & 3,675 & - \\
\hline June & 4,338 & $\mathbf{3 , 8 0 6}$ \\
\hline Monthly Average & $\mathbf{3 , 7 5 8}$ & \\
\hline P: Provisional & & \\
Source : PBS & \multicolumn{2}{|}{} \\
\hline
\end{tabular}




\section{Fig-9: Monthly Imports (S Million)}

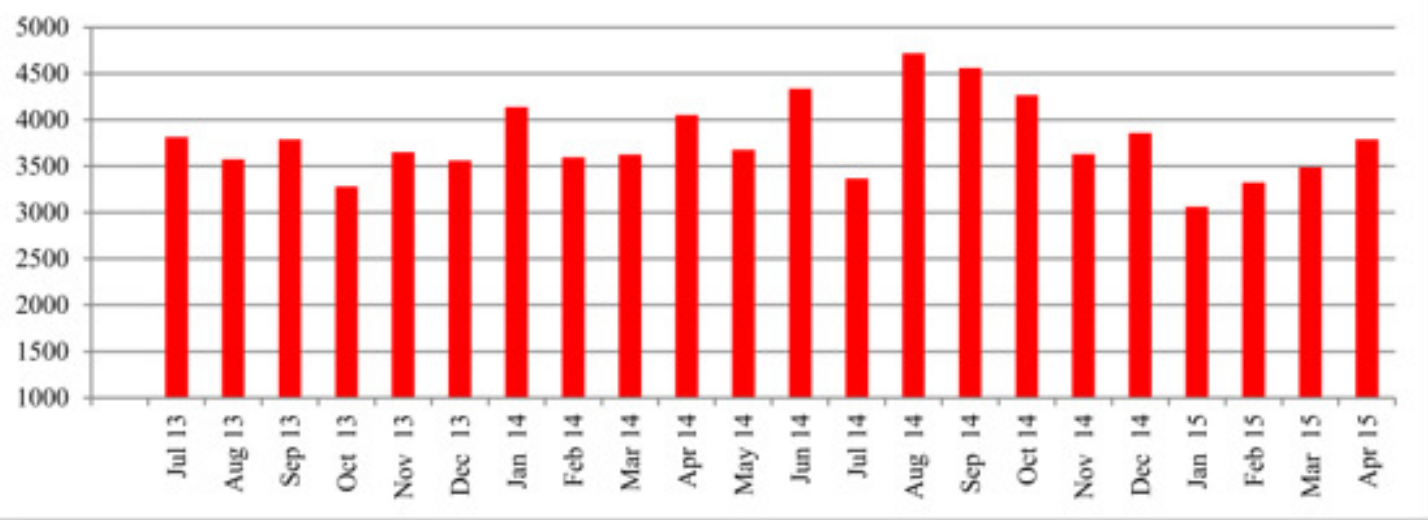

\section{Concentration of Imports}

Pakistan's imports, like its exports are not well diversified both in terms of countries and products, and are restricted to few countries. As per the recent trends, more than half of the imports of Pakistan originate from countries like Saudia Arabia, UAE, India, Indonesia, Kuwait etc. The dependency of Pakistan on China for its imports has seen a dramatic increase from 17 percent to 23 percent (2014-15) in comparison to the last year.

\begin{tabular}{|c|c|c|c|c|c|c|c|c|c|c|c|c|}
\hline \multicolumn{9}{|c|}{ Table 8.11 : Major Imports Markets } & \multicolumn{4}{|c|}{ (Rs. billion \& Percentage Share) } \\
\hline \multirow[t]{2}{*}{$\overline{\text { Country }}$} & \multicolumn{2}{|c|}{$2009-10$} & \multicolumn{2}{|c|}{$2010-11$} & \multicolumn{2}{|c|}{$2011-12$} & \multicolumn{2}{|c|}{$2012-13$} & \multicolumn{2}{|c|}{$2013-14$} & \multicolumn{2}{|c|}{$\begin{array}{c}\text { July-March } \\
2014-15 \text { P }\end{array}$} \\
\hline & Rs & \begin{tabular}{|c|}
$\%$ \\
Share \\
\end{tabular} & Rs & \begin{tabular}{c|}
$\%$ \\
Share
\end{tabular} & Rs & $\begin{array}{c}\% \\
\text { Share } \\
\end{array}$ & Rs & $\begin{array}{c}\% \\
\text { Share } \\
\end{array}$ & Rs & $\begin{array}{c}\% \\
\text { Share } \\
\end{array}$ & Rs & $\begin{array}{c}\% \\
\text { Share } \\
\end{array}$ \\
\hline$\overline{\text { U.A.E }}$ & 422.0 & 14 & 469.5 & 14 & 685.1 & 17 & 837.4 & 19 & 757.1 & 16 & 515.1 & 15 \\
\hline China & 370.2 & 13 & 494.9 & 14 & 685.1 & 17 & 642.4 & 15 & 793.0 & 17 & 776.0 & 23 \\
\hline Kuwait & 201.8 & 7 & 284.8 & 8 & 358.8 & 9 & 392.5 & 9 & 346.7 & 7 & 196.0 & 6 \\
\hline Saudi Arabia & 283.6 & 10 & 388.8 & 11 & 449.6 & 11 & 334.5 & 8 & 459.1 & 10 & 262.1 & 8 \\
\hline
\end{tabular}

\begin{tabular}{|c|c|c|c|c|c|c|c|c|c|c|c|c|}
\hline \multicolumn{9}{|c|}{ Table 8.11 : Major Imports Markets } & \multicolumn{4}{|c|}{ (Rs. billion \& Percentage Share) } \\
\hline \multirow[t]{2}{*}{ Country } & \multicolumn{2}{|c|}{$2009-10$} & \multicolumn{2}{|c|}{$2010-11$} & \multicolumn{2}{|c|}{$2011-12$} & \multicolumn{2}{|c|}{$2012-13$} & \multicolumn{2}{|c|}{$2013-14$} & \multicolumn{2}{|c|}{$\begin{array}{c}\text { July-March } \\
2014-15 \text { P }\end{array}$} \\
\hline & Rs & $\begin{array}{c}\% \\
\text { Share }\end{array}$ & Rs & $\begin{array}{c}\% \\
\text { Share }\end{array}$ & Rs & \begin{tabular}{|c|}
$\%$ \\
Share
\end{tabular} & Rs & \begin{tabular}{|c|}
$\%$ \\
Share
\end{tabular} & Rs & $\begin{array}{c}\% \\
\text { Share }\end{array}$ & Rs & $\begin{array}{c}\% \\
\text { Share }\end{array}$ \\
\hline Malaysia & 146.3 & 5 & 210.3 & 6 & 216.9 & 5 & 202.9 & 5 & 174.4 & 4 & 70.7 & 2 \\
\hline Japan & 128.8 & 4 & 142.2 & 4 & 171.4 & 4 & 197.3 & 5 & 182.6 & 4 & 123.2 & 4 \\
\hline India & 102.9 & 4 & 149.0 & 4 & 134.8 & 3 & 175.5 & 4 & 210.5 & 5 & 134.1 & 4 \\
\hline U.S.A & 135.0 & 5 & 154.7 & 4 & 132.0 & 3 & 156.6 & 4 & 180.1 & 4 & 127.9 & 4 \\
\hline Germany & 98.7 & 3 & 80.2 & 2 & 100.1 & 2 & 131.0 & 3 & 126.1 & 3 & 71.5 & 2 \\
\hline Indonesia & 53.8 & 2 & 68.8 & 2 & 104.4 & 3 & 125.3 & 3 & 162.7 & 4 & 157.1 & 5 \\
\hline All Other & 967.9 & 33 & $1,012.2$ & 29 & 970.9 & 24 & $1,154.4$ & 27 & $1,238.2$ & 27 & $1,004.3$ & 29 \\
\hline Total & $2,911.0$ & 100 & $3,455.3$ & 100 & $4,009.1$ & 100 & $4,349.9$ & 100 & $4,630.5$ & 100.0 & $3,438.0$ & 100.0 \\
\hline
\end{tabular}

Source: Pakistan Bureau of Statistics

P: Provisional

\section{Comparison of Pakistan's Imports with the Emerging Economies of the World}

The comparison of Pakistan's imports with the few economies of the world indicates the proportion of imports that Pakistan contributes relative to these countries. The imports of goods and services in Pakistan has been discussed in relation to the countries like Bangladesh, Brazil, India, Malaysia, Indonesia, Singapore along with their GDP that reflects the growth rate during the last 3 decades. (1985-2014) Following tables and graphs illustrate the import of goods and services in US dollars in the respective countries: 


\begin{tabular}{|c|c|c|c|}
\hline \multicolumn{4}{|c|}{ Time Series Data 1985 - 2014 (30 Years of Data) } \\
\hline \multicolumn{4}{|c|}{ Imports of goods and services (current US\$) } \\
\hline Country Names & 1985 - 1994 & $1995-2004$ & $2005-2014$ \\
\hline Bangladesh & $3,640,142,337$ & $8,660,809,379$ & $27,640,187,627$ \\
\hline Brazil & $30,036,045,025$ & $77,423,972,179$ & $240,555,059,538$ \\
\hline India & $23,946,711,464$ & $69,625,222,020$ & $404,530,381,894$ \\
\hline Indonesia & $26,690,758,593$ & $53,267,782,571$ & $160,514,699,682$ \\
\hline Malaysia & $32,708,373,066$ & $90,122,957,708$ & $180,622,820,579$ \\
\hline Pakistan & $8,761,918,209$ & $12,095,487,998$ & $36,641,734,550$ \\
\hline Singapore & $59,719,918,801$ & $158,191,926,127$ & $400,584,476,824$ \\
\hline
\end{tabular}

The graph indicating the imports of goods and services of the respective table is as under:

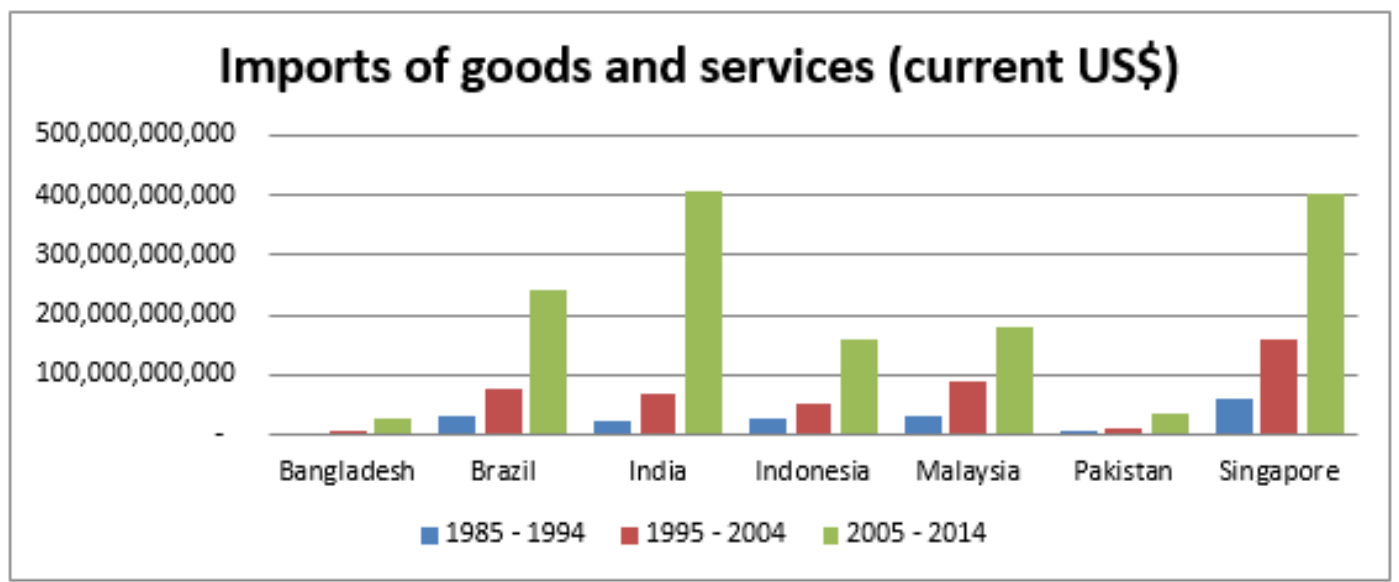

To evaluate the GDP in the same duration with respect to the similar countries to examine the impact of imports on economic growth, the table along with the graph is as follows:

\begin{tabular}{|l|r|r|r|}
\hline \multicolumn{5}{|c|}{ Time Series Data 1985 - 2014 (Almost 25 Years of Data) } \\
\hline Country Names & $\mathbf{1 9 8 5} \mathbf{- 1 9 9 4}$ & \multicolumn{1}{|c|}{ GD95 - 2004 } & $\mathbf{2 0 0 5 - 2 0 1 4}$ \\
\hline Bangladesh & 3.97 & 4.82 & 6.20 \\
\hline Brazil & 3.07 & 2.66 & 3.47 \\
\hline India & 5.31 & 6.25 & 7.69 \\
\hline Indonesia & 7.01 & 3.13 & 5.72 \\
\hline Malaysia & 7.10 & 5.33 & 4.94 \\
\hline Pakistan & 5.49 & 3.87 & 4.02 \\
\hline Singapore & 7.90 & 5.29 & 5.89 \\
\hline
\end{tabular}

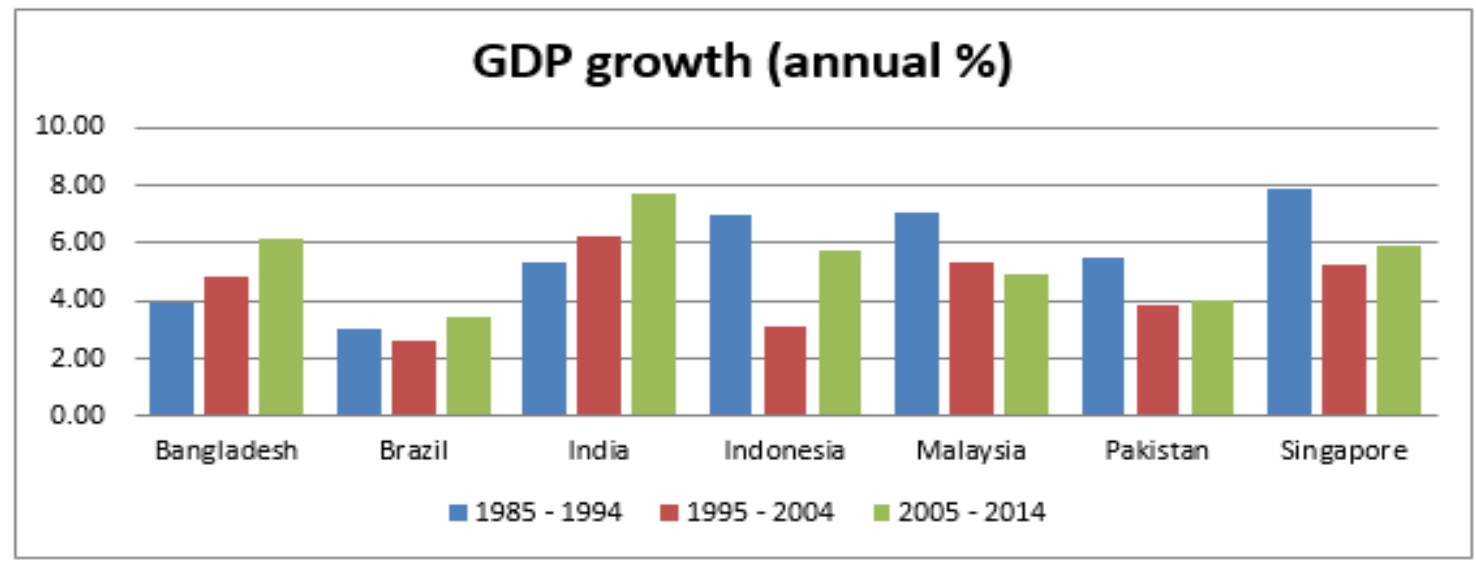


Objective of the Study:

The main objectives of the particular research are as follows:

1. To empirically investigate the impact of imports in the economic growth of Pakistan over a period of approximately 40 years. (1975-2014)

2. To study the casual relationship between imports and economic growth in Pakistan.

3. To suggest policy implications with respect to imports in Pakistan.

4. To understand the importance of imports on economic growth in Pakistan.

\section{Hypotheses:}

Based on the particular objectives that have been researched through empirical testing, the following hypotheses were formulated:

\section{H1: There is a significant relationship between imports and economic growth in Pakistan.}

H2: There is a significant impact of imports on the economic growth in Pakistan. H3: There is a significant impact of economic growth on imports in Pakistan.

\section{Data and Methodology}

For this particular study, the Time series data was utilized for Pakistan to examine the relationship between two variables over a period of 40 years from 1975 to 2014. The variables that are a part of this study include the import of goods and services in Pakistan and the change in Real Gross Domestic Product (GDP) which is an evaluator of economic growth. The data has been extracted from World development indicators, Pakistan Bureau of Statistics, State bank of Pakistan and Economic Survey of Pakistan.

\section{Method}

The method that has been utilized in this research paper includes the Granger causality test that is used to measure the directional causality between variables. Both variables such as GDP and imports are investigated and analyzed to find out their statistical significance.

\section{Data Analysis Procedure}

Time series data analysis has been carried out to examine the trends in the last 25 years on the import and economic growth in Pakistan. Along with the Granger causality test, the regression model would also be used to find out the level of significance of imports on the economic growth in Pakistan. For this particular purpose, E-Views (5 Version) has been utilized to serve purpose to this paper.

\section{Research Model}

The econometric model that can be developed for examining the effects of imports on the economic growth is as follows:

$$
\mathbf{Y}_{\mathbf{i}}=\mathbf{B} \mathbf{0}+\mathbf{B}_{1} \mathbf{X}+\mathbf{E i}
$$

As per the given research, we would examine the causal relationship between imports and growth. So, the econometric model for the study is given as:

$$
\mathbf{G D P}=\mathbf{B}_{0}+\mathbf{B}_{1} \mathbf{I M P}+{ }_{\mathbf{E i}}
$$

Where,

GDP $=$ Economic Growth in Pakistan in US \$ (Current)

$\mathrm{B}_{0}=$ Intercept

$\mathrm{B}_{1}=$ Slope

IMP = Independent Variable (Import)

$\mathrm{Ei}=$ Error Term

\section{REGRESSION TEST}

The regression test has been used to examine the level of significance between the two variables. The simple regression model reflects the following results: 


\section{IMPORT \& ECONOMIC GROWTH}

Dependent Variable: GDP

Method: Least Squares

Date: 05/03/16 Time: 15:59

Sample: 19752014

Included observations: 40

\begin{tabular}{lrlrr}
\hline \hline \multicolumn{1}{c}{ Variable } & Coefficient & Std. Error & t-Statistic & Prob. \\
\hline \multicolumn{1}{c}{ C } & 26.50595 & 5.054715 & 5.243808 & 0.0000 \\
\multicolumn{1}{c}{ IMP } & -2.246231 & 0.951078 & -2.361773 & 0.0234 \\
\hline \hline R-squared & 0.128000 & Mean dependent var & 15.52750 \\
Adjusted R-squared & 0.105052 & S.D. dependent var & 13.27458 \\
S.E. of regression & 12.55797 & Akaike info criterion & 7.947295 \\
Sum squared resid & 5992.699 & Schwarz criterion & 8.031739 \\
Log likelihood & -156.9459 & Hannan-Quinn criter. & 7.977827 \\
F-statistic & 5.577969 & Durbin-Watson stat & 0.204841 \\
Prob(F-statistic) & 0.023415 & & \\
\hline \hline
\end{tabular}

According to the result produced by the regression analysis, the value of Adjusted $\mathrm{R}$ - Squared reveals that only 10 percent of the variation has been found due to the imports. This implies that import influences the economic growth. Moreover, the impact of 10 percent on economic growth is significant as the probability lies under the 5 percent level of significance. Furthermore, the rest 90 percent of the economic growth is influenced by other factors that are also present in the significant level.

Moreover, the Granger Causality test reflected the following values:

Dependent Variable: GDP

Method: Least Squares

Date: 05/03/16 Time: 16:05

Sample (adjusted): 19772014

Included observations: 38 after adjustments

\begin{tabular}{lrlrr}
\hline \hline \multicolumn{1}{c}{ Variable } & Coefficient & Std. Error & t-Statistic & Prob. \\
\hline \multicolumn{1}{c}{ C } & 0.550921 & 0.737543 & 0.746968 & 0.4601 \\
GDP(-1) & 0.969680 & 0.171890 & 5.641275 & 0.0000 \\
GDP(-2) & 0.074713 & 0.186411 & 0.400799 & 0.6910 \\
\hline \hline R-squared & 0.955810 & Mean dependent var & 16.21316 \\
Adjusted R-squared & 0.953285 & S.D. dependent var & 13.26962 \\
S.E. of regression & 2.868055 & Akaike info criterion & 5.020802 \\
Sum squared resid & 287.9008 & Schwarz criterion & 5.150085 \\
Log likelihood & -92.39523 & Hannan-Quinn criter. & 5.066800 \\
F-statistic & 378.5170 & Durbin-Watson stat & 1.965332 \\
Prob(F-statistic) & 0.000000 & & \\
\hline \hline
\end{tabular}

The results of the Granger's Causality Test are as follows:

Pairwise Granger Causality Tests

Date: 05/03/16 Time: 16:06

Sample: 19752014

Lags: 2

\begin{tabular}{lccc}
\hline \hline Null Hypothesis: & Obs & F-Statistic & Prob. \\
\hline \hline IMP does not Granger Cause LOG(GDP) & 38 & 4.80179 & 0.0148 \\
LOG(GDP) does not Granger Cause IMP & & 2.54285 & 0.0940 \\
\hline \hline
\end{tabular}

According to the output revealed through Pairwise Granger Causality Tests, the probability value is under the level of significance that indicates that null hypothesis is rejected which implies that import has a significant impact 
on the economic growth in Pakistan and economic growth has a significant impact on the imports. The results reveal that there is a bi-directional causality between imports and economic growth in Pakistan.

\section{CONCLUSION}

This paper examined the impact of imports on the economic growth in Pakistan and showed the positive and significant relationship between the two variables. The analysis has been suggested by investigating the causal relationship between the imports and GDP in Pakistan and the result significantly reflected the bi-directional causality. The data was over a period of 40 years starting from 1975 to 2014. In a nutshell, this study advocates the fact that the GDP is influenced significantly by the imports and vice versa in Pakistan.

\section{POLICY IMPLICATIONS}

The policy implications of this study are to suggest the government to formulate policies that are directed towards imports of those capital goods such as machinery group, equipment, chemicals, etc. along with those consumer goods that can translate in to the productivity and growth of the economy in Pakistan. These policies can translate the imports to channelize the production process more efficiently and can contribute towards export oriented productivity thereby offsetting the negative impact of reduction in the valuable foreign exchange.

Similarly, by channelizing the imports in the fair manner and execution of growth related policies with respect to imports, the economic growth in Pakistan will be much more productive in comparison to the past decades. For further research, the right mix of the categories and products should be examined to accelerate the pace of economic growth through imports in Pakistan.

\section{REFERENCES}

1. Hogendorn,J. S.’’ Economic Developmen’’ 3rd ed., arper Collins, C 1996.

2. Lee, Jong-Wha,"Capital Goods Imports and Long-run Growth", Journal of Development Economics, Vol.48, 1995.

3. Rivera-Batiz, F.L. (1985). International Finance and Open Economy Macroeconomics. New York: Macmillan

4. Grossman, G.M., and E. Helpman (1991). Innovation and Growth in The Global Economy. Cambridge:MIT Press.

5. Esfahani, H.S. (1991). Exports, Imports and Economic Growth in Semi-Industrialised Countries. Journal of Development Economics 35:93-116

6. Riezman R. G, P. M. Whiteman and C. H. Summers,'The Engine of Growth or its Handmaiden? A TimeSeries Assessment of Export-Led Growth", Economic

7. Yuhong Li, Zhongwen Chen \& Changjian San (2010), Research on the Relationship between Foreign Trade and the GDP Growth of East China - Empirical Analysis Based on Causality, Modern Economy, Vol. 1, pp. 118-124

8. Asafu-Adjaye, J and D Chakraborty. (1999), 'Exportled Growth and Import Compression: Further Time Series Evidence from LDCs', Australian Economic Papers, 38, pp. 164-75.

9. Hussain M and Saaed Afaf (2014)"Relationship between Exports, imports, and economic growth in Saudi Arabia: 1990-2011. Evidence from cointegration and Granger causality analysis” Journal of Emerging Trends in Economics and Management Sciences (JETEMS) 5(3):364-370.

10. Kotan, Z., and M. Sayg1lı (1999). Estimating An Import Function for Turkey. Discussion Paper No.9909, The Central Bank Of The Republic Of Turkey

11. Baharumshah, A.Z., and S. Rashid (1999). Exports, Imports and Economic Growth in Malaysia: Emprical Evidence Based on Multivariate Time Series. Asian Economic Journal 13(4):389-406.

12. Awokuse, T.O. (2007). Causality Between Exports, Imports and Economic Growth: Evidence from Transition Economies. Economics Letters 94:389-95.

13. Rana H (2002). The impact of imported and domestic technologies on the productivity of firms: panel data evidence from Indian manufacturing firms. J. Dev. Econ., 69(1): 23-49. 